\title{
EVALUATING THE FACTORS FOR FISCAL STABILITY OF RURAL MUNICIPALITIES: THE CASE OF BULGARIA
}

\author{
SVETLANA KOLEVA ALEKSANDROVA-ZLATANSKA
}

\begin{abstract}
The issue of financial stability and sustainability affects the autonomy of local governments and their fulfilment of delegated obligations. This paper examines the financial stability of Bulgarian rural municipalities and the impacts of the economic, demographic and economic factors on their financial performance. It covers all 231 rural municipalities in Bulgaria. The purpose of this paper is to explore the capability of local governments to fulfill the financial indicators which are defined by the Bulgarian Public Finance Act (2017). The author proposes a model for the assessment of financial stability of rural municipalities that can be used by local authorities at all levels for monitoring the financial management of rural municipalities and for evaluating their propensity to follow defined fiscal indicators.
\end{abstract}

Keywords: rural municipalities, financial stability, fiscal stability, evaluation model, financial indicators, financial discipline.

JEL Codes: H10, H11, H70.

\section{Introduction}

Generally speaking, financial stability relates to the overall economic development of the municipality and the capacity of local governments to accumulate sufficient financial resources, to provide public services and to manage debt, to name just a few. Financial stability is a broad concept which defines the flexibility of planinig and executing of the allocated budget with the aim of saveguarding the budget from the external shocks and any unprecedented costs. The main charac- 
teristic of financial stability is the ability of a municipality to meet its administrative and capital (investment) needs, which involves maintaining and developing its own assets in accordance with the current and future demand for the provision of public services and, at the same time, adapting to possible external factors (Hendrick, 2004; 2011).

Good financial management at the local level is, therefore, crucial for the delivery of goods and services. Financial discipline is one of the cornerstones of good financial management, the success and continuity of any municipality. It ensures that financial resources are properly managed and spent in accordance with the pre-determined priorities of the respective municipality. The author's view is that financial discipline is one of the fundamental components of municipal financial management and it is essential for the fulfilment of the functional commitments of municipalities and ensuring the sustainability of municipal governance.

The financial stability of Bulgarian municipalities is a current issue because of the need to strengthen their capacity for implementing the projects financed by the European Union (EU) structural and investment funds. Co-financing provided for the EU projects, however, is a considerable fiscal burden for local governments and it could easily undermine their financial stability. More specifically, financial stability poses serious concerns to small municipalities.

In Bulgaria, municipalities differ considerably in size, economic potential, population size and density. These differences are used for the division of Bulgarian municipalities in two groups: rural municipalities and developed urban municipalities. The main features of Bulgarian rural municipalities are presented below.

\section{Main features of Bulgarian rural municipalities}

Bulgaria is divided into six planning regions (NUTS 2 level), 28 districts (district is a central government territorial administration, with governors appointed by the Council of Ministers, (NUTS 3 level), and 265 municipalities (LAU 1). According to the national definition ${ }^{1}$, the rural regions encompass the territories of 231 municipalities, which comprise $37 \%$ or 2.3 million of the total population.

At present, $23 \%$ of municipalities have up to 5000 citizens, $28 \%$ have up to 10,000 inhabitants; $19 \%$ of the inabitants live in settlements from 10,000 to 20,000 citizens, and $18 \%$ of the inhabitants live in settlements ranging from 20,000 to 30,000 citizens. Rural municipalities have population below 30,000.

The urban territory in rural areas comprises $24 \%$ of the population and $22 \%$ of the population lives in villages as well. The number of inhabitants who live in the cities is 5.1 million or $73.7 \%$, and in the villages 1.8 million or $26.3 \%$ of the total country's population (NSI, 2018). The population in rural municipalities is $34 \%$

\footnotetext{
${ }^{1}$ The national rural regions definition provides a typology of the territories at the level of municipality (LAU1), unlike the EU definition, which is at the level of district (NUTS 3). The major criterion for the national definition is the number of the population inhabiting the largest settlement in the municipality, unlike the EU definition where the main criterion is the density of the population. According to the national definition, the rural regions include all municipalities where the population of the largest settlement does not exceed 30,000 people.
} 
of the total population of Bulgaria and $66 \%$ of the people live in municipalities with more 30 than 000 inhabitants (NSI, 2018). At the end of 2018, the number of the population in rural areas (small towns and villages) was 2.3 million, which is around $37 \%$ of the entire country's population. The changes in population figures result from migration from rural to urban areas within the country, negative birth rate, lack of opportunities for young people to find jobs and/or to develop professionally.

Throughout the period between 2010 and 2018 the number of people in the rural regions of Bulgaria continued to decline. The decrease rate of the population in rural regions is higher than the average rate for the country. During this period, the population in rural areas declined by $14.5 \%$ as a consequence of mobility of the population to urban areas or outside of the country. The major reason for the decline and loss of population in the rural regions is the negative natural birth rate, the migration and mobility of the work force to the towns. The age group of the population in the rural areas and in the country as a whole is unfavourable. The population below 15 years of age is low, around $6 \%$, it is significantly lower than in the urban areas, where it is $15 \%$ - and for the whole country $-20 \%$. By contrast, the share of the population aged 65 and above, is $22 \%$ in comparison to the overall data which is at $19 \%$ for Bulgaria (NSI, 2018).

The population in working age for the observed period (2010-2018) declined by $12 \%$ due to a decrease in the population around $6 \%$ and increase in the population above 65 age by $5 \%$. The economically active population in working age in rural settlements is $41 \%$ of the total economically active people in the country. Most of the people in working age (around 76\%) reside in towns and only $24 \%$ in villages (NSI, 2018).

The annual unemployment rate was $4.7 \%$ in 2018 , which is a fluctuation from 10 to $20 \%$. However, there are some cities and villages where the uneployment rate reached above $25 \%$ and more (NSI, 2018). The trend of high annual unemployment rate has not changed for the poorest regions in the country (i.e. North-West and North-East regions) due to the low level of education and qualification of the workforce, and lack of industrial enterprises. The municipalities with high unemployment rates are too distant from the main economic centers; as a result, a typical feature for them is labour mobility to big city or to municipal center. This trend will be difficult to overcome because of the restricted labour market and risk of longer lasting isolation from the labour market.

There are also differeneces across municipalities in terms of enterprise output. The enterprise production in rural areas reached $21 \%$ of the total, while the production in big munucipalities was 79\% (NSI, 2018).

Overall, Bulgarian population, particularly outside the urban areas, is shifting towards an older population, which poses a serious and real financial risk for rural local authorities because of increasing costs for covering greater demand for care-related services and facilities for the elderly. Harisanova and Stoynova (2012) underline the negative impact of demographic changes and population shifts on depopulation of villages in Bulgaria. 
Financing of local government in Bulgaria is regulated by the several acts: Public Finance Act (2017), Municipal Budget Act (2013), State Budget Act (2018) and Local Taxes and Fees Act (2019). The financial interaction of the municipal with the central budget is regulated by the State Budget Act (2018). The budget transfers from the state budget to the municipal budget are for delegated duties, capital expenditure and, in addition, grants from European Agricultural Fund for Rural Development. Currently, each municipal government runs its own budget, and raises revenues from various sources. The sources include user fees and income from private sector activities; in addition, municipal governments in Bulgaria obtain funds mainly from public subsidies, real estate tax, transport vehicle tax, succession tax, waste collection fees and administrative services' fees, and the EU project grants ${ }^{2}$. Additional intergovernmental transfers are equalizing subsidies targeted to ensure a minimum level of local services in the municipalities and to equalize the revenues from local taxes to the average for the country revenue level. The subsidies for capital expenditure are allocated by criteria, including population size, number of cities/towns, size of the municipal territory, to name just a few.

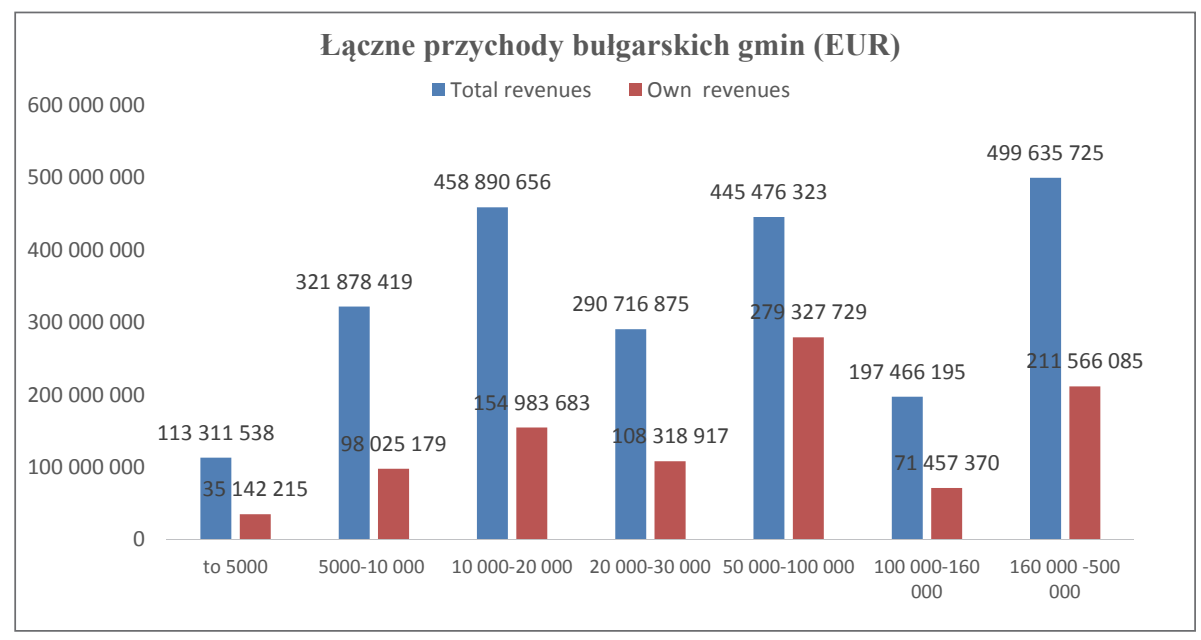

Fig. 1. Total and own revenues allocated to municipalities of different size ${ }^{3}$.

Source: Ministry of Finance Statistics (2018) and author's own calculations.

\footnotetext{
${ }^{2}$ Data from the Bulgarian municipalities' budgets is used in the article. Public subsidies provided to municipalities from the EU funds and other targeted subsidies fall outside the said budgets and, therefore, such data is not included in the present empirical analysis. Future studies will focus on the effects of additional public subsidies funding on the financial stability and fiscal discipline of the municipalities in Bulgaria.

${ }^{3}$ The own revenues of the Bulgarian municipalities represent the difference between the total annual budget and the delegated funds provided by the national budget of the country. The allocation of delegated funds is planned on an annual basis and forms part of the National Budget (to serve social activities, education, culture, etc.).
} 
The total annual revenues of rural municipalities are around EUR 1.2 billion. The municipalities' own revenue recorded for all rural municipalities is EUR 396.5 millon or $31 \%$ of the total municipalities'own revenues. The larger municipalities' own revenue of (30,000-500,000 inhabitans) is EUR 562.4 million, which is higher by $42 \%$ than rural municipalties.

The amount of intergovernmental transfers from the central government to municipalities is essential to the total municipal financial capacity. The bigger sized municipalities receive larger portion of their income from their own revenues, whereas smaller municipalities, mostly rural municipalities, continue to depend heavily on state budget subsidies and other grants. Small communities do not have enough capacity to mobilize their own revenue and for that reason they are incapable to deliver qualitative public services. As a result of the difference in fiscal capacity and expenditure needs, fiscal disparities have been observed among Bulgarian municipalities. Municipalities have different expenditures and revenue bases, but all their expenditures are funded from transfers, own revenues or borrowing. The tax and own revenues are highly constrained in particular for small municipalities, because of low levels of employment and economic activity as well as restricted business activities.

\section{Assessment of the capability of rural municipalities to maintain financial stability}

There is a plethora of publications and studies examining the different definitions and criteria devoted to financial stability, sustainability and fiscal discipline of municipalities. However, there is lack of research devoted to fiscal discipline and its relevance to financial stability.

For example, the Organisation for Economic Cooperation and Development (OECD) defines financial sustainability as "an ability of local government to maintain public finances at credible and serviceable position over the long term" (OECD, 2013, p. 50).

According to the EU (2011) legislation, financial sustainability can be defined as the ability to finance public services without compromising the future capacity or incurring risks of spending decrease. The definition brings together the key elements of financial health, namely, service provisions, infrastructure requirements, and needs of the local community.

The models characterizing the financial stability of municipalities usually analyze the impact at the socio-economic, demographic and political levels. Wang, Dennis and Sen (2007) summarize different approaches and consider that the socio-economic environment is only one of the factors (among others) to be taken into account when analyzing the financial situation. On the other hand, Kloha, Weissert and Kleine (2005) consider that socio-economic factors affect local finances and should not be included as an additional factor in the analysis of the financial situation.

In Bulgaria, the Ministry of Finance is responsible for observing the financial performance and the financial sustainability of municipalities through defined finan- 
cial indicators ${ }^{4}$. The Ministry of Finance's methodology sets out the main indicators that are key for assessing the execution of municipal's budget. The municipalities that do not satisfy the criteria set in the Ministry of Finance's methodology are required to present a plan for financial recovery.

The Public Finance Act defines financial autonomy of the municipality as the ability to generate own revenues, which are at least 50 percent and more than the total revenue in the budget, then the municipality is relatively autonomous from the central government. In other words, the municipality manages to finance the costs of local activity with its own revenues. Fiscal discipline within the framework of this study means the set fiscal parameters with the implementation of Article 130a of the Public Finance Act ${ }^{5}$.

\section{Methodology}

The evaluation model presented in this paper includes socio-economic factors and financial stability indicators of Bulgarian municipalities which are regulated by the Public Finance Act. The model uses statistical methods (correlation and regression analyses $)^{6}$ that estimate the dependence between socio-economic, demographic and financial factors and municipal's fiscal position. The methodology aims at elaborating two indices for estimation of fiscal discipline and to test the degree of execution of the implementation of the defined financial indicators.

The evaluation model is developed in the following consecutive stages: the identification of factors that can determine or at least affect the financial condition; the assessment of correlation relationships between economic, social and demographic variables and financial variables, which define the financial state of municipalities; and calculation of composite rating indices for all rural municipalities in the country.

The scope of the evaluation model with regard to the data used for its construction is limited to the available public information on individual indicators by municipality. In particular, the study has selected indicators for which information is available for all municipalities. Data for financial indicators are taken from the Ministry of Finance and data on the socio-economic indicators are taken from the National Statistical Institute. To ascertain the financial stability in rural areas, available information is used from the Ministry Finance for financial statement of rural municipalities. All 231 rural municipalities are included in the evaluation model.

\footnotetext{
${ }^{4}$ The indicators are defined in accordance with the relevant requirements under Article 130a, paragraph 1 of the Public Finance Act (2016) (criteria for financial sustainability) and Article 32, paragraphs 1 and 2 of the Public Finance Act (fiscal rules).

${ }^{5}$ The Ministry of Finance periodically publishes the data on the financial situation of the municipalities and municipalities with deteriorated financial situation develop a plan for financial rehabilitation.

${ }^{6}$ Correlation analysis identifies the statistical relationship between the factors impact on financial stability, and regression analysis determines the functional dependencies.
} 


\section{Description of the evaluation model and main faindings}

A correlation analysis has been made ${ }^{7}$ with the aim to assess the degree of dependence between the financial indicators and demographic and economic factors. The indicators included in the composite indices are based on the findings of correlation. A correlation between financial indicators - "revenue share of total proceeds" and "covering the costs of local activities with revenue" - and economic varibles - "unemployment rate" and "average annual income per person (BGN)" is significant. Municipalities with high unemployment rate and low income of the population are highly sensitive to the fluctuation of their own revenues. Improving macroeconomic characteristics is directly linked to generating more own revenues in the future. The correlation analysis shows that municipal financial conditions are dependent on the unemployment rate, which means that municipal revenues decrease in parallel with the decline of the economic activity.

Regarding the estimation of the relationship between financial indicators and financial stability at the municipal level, the correlation shows a strong dependency between the tax collection rate (real estate tax (\%), vehicle tax (\%)) and economic indicators (long-term unemployed, unemployment rate (\%) and average annual income per person (BGN)).

The correlation is moderate between the indicators "Number of residents per one municipal official" and variables unemployed up to 29 years of age, longterm unemployed and unemployment rate (\%). The correlation between the budget balance and the number of population is moderate, which shows that in reality less busy municipalities are more inclined to form a deficit. This higher sensitivity should be taken into account in the forming of buffers in financial management and could become a cause of low fiscal discipline due to the greater sensitivity to possible external shocks. In this respect, Petrov (2017, p. 54) notes "that financial performance of rural municipalities is a problem of the ability of the administration to adequately fulfill their commitments to conduct policies for local economy development".

In the developed model for assessing the propensity of rural municipalities to respect financial discipline, two composite indices are constructed: the first one (K1) assesses the economic, social and administrative potential of the municipality and the second one (K2) - measures the propensity to violate fiscal discipline, i.e. an assessment of the ability of the municipality and its management to observe the rules of fiscal discipline. For each of these two indices, an individual evaluation equation has been drawn up.

The index consists of economic variables that have a strong correlation with the financial condition of the municipality.

\footnotetext{
${ }^{7}$ The scale used to determine the relevance of the link is: $0-0.2$ - poor correlation; $0.2-0.4$ - moderate correlation; 0.4-0.6 - significant correlation; 0.6-0.8 - high correlation; 0.8-1 - very high correlation.
} 


\section{Index K1 Assessment of the economic, social and administrative potential of} the municipality is defined as follows:

$$
K 1=\ln (1+A)+\ln (1+B)+\ln (1+C)+\ln (1+D)-\ln (1+k)+\ln \left(1+\frac{n}{\max (n n)}\right)+\ln \left(1+\frac{m}{\max (m m)}\right)
$$

or

$$
K 1=\ln \left(\frac{(1+A) *(1+B) *(1+C) *(1+D)}{(1+k)} *\left(1+\frac{n}{\max (n n)}\right) *\left(1+\frac{m}{\max (m m)}\right)\right)
$$

where:

$A \quad-$ share of the revenue from the total proceeds,

$B-$ covering the costs of local activities with revenue,

C - number of residents per one municipal official,

$D \quad-$ share of wage and social security costs from the total costs,

$k-\quad$ unemployment rate $(\%)$,

$n \quad-$ average annual income per person (BGN),

$\max (n n)$ - maximum value of the variable Average annual income per person (BGN) for the municipalities in the sample,

$m$ - production of enterprises (BGN thousand),

$\max (\mathrm{mm})-$ maximum value of the variable Production of enterprises (BGN thousand) for the municipalities in the sample.

The results of regression show that the indicator "share of revenues of the total proceeds" (A), depends on the economic and social profile of the municipality. The higher value of the indicator means that local government has the ability to resist the external financial and economic impacts. Another variable is "covering the costs of local activities with revenue" (B), which directly measures how the local government observes financial discipline. The higher value indicates the capacity of the municipality to resist to external impacts. The variable "number of residents per one municipal official" (C) measures the effectiveness of local governmental administration to serve the population. Indicators "share of the cost for salaries and benefits of the total costs" (D) and social security costs of the total costs are included to take into account the optimization of the workload of the municipal administration. The unemployment rate $(\mathrm{k})$, the average annual income per person and the production of enterprises measure the socio-economic development of the municipality. The average income per person (n) and the production of enterprises affect the finances of the municipality, but it is in a reverse relation with the unemployment level, which is also a reason for the deterioration of the financial condition of the municipality. 
Index $\mathrm{K} 2$ measures the propensity for violation of fiscal discipline and is expressed by the following logarithmic equation:

$$
K 2=\ln (1+G)-\ln (1+E)-\ln (1+F)+\ln (1+S * H)+\ln \left(\frac{I}{\operatorname{aver}(I I)}\right)+\ln \left(\frac{J}{\operatorname{aver}(J J)}\right)
$$

or

$$
K 2=\ln \left(\frac{(1+G) *(1+S * H) * I * J}{(1+E) *(1+F) * \operatorname{aver}(I I) * \operatorname{aver}(J J)}\right)
$$

where:

$G \quad-$ the budget balance compared to total revenues,

$E \quad-$ debt size as a\%age of planned revenue and equalization subsidy,

$F \quad-$ overdue liabilities as a\%age of planned revenue and equalization subsidy,

$H \quad$ - share of capital expenditure in total costs (investment activity),

I $\quad-$ tax collection rate on real estate (\%),

aver(II) - average value of the index tax collection rate on real estate (\%) for all municipalities in the sample,

$J \quad-$ tax collection rate on vehicles (\%),

aver $(J J)$ - average value of the index tax collection rate on vehicles (\%) for all municipalities in the sample,

$S-$ is indicative of whether the municipality has overdue liabilities or:

$$
S=\left\{\begin{array}{l}
F>0 \rightarrow S=-1 \\
F \leq 0 \rightarrow S=1
\end{array}\right.
$$

Financial variables included in the above equitation define the financial management of the local government. Budget balance compared to total revenues (G) is a key variable for assessing the fiscal state. An additional condition in this case is that the greater the balance at the end of the year (as a\%age or relative share of the magnitude of the expenditure of the municipality), the weaker the ability to precisely plan revenue and expenditure in this municipality. The positive budget balance testifies to the existence of good fiscal discipline, while the opposite testifies to a low one.

"Debt size as a\%age of planned revenue and equalization subsidy" (E) is a variable for the assessment of the financial situation and the structure of the debt for the current year. The high value has a negative impact on the municipal's finances and leads to deterioration of the fiscal stability.

The variable "overdue liabilities as a\%age of planned revenue and equalization subsidy" (F) shows the quality of the financial management of the municipality and the extent to which financial commitments are fulfilled. The existence of 
large delays (such as a gross amount and, more importantly, as a relative weight of the planned revenue) burden the municipality financially with a commitment that translates into subsequent periods and breaks the financial planning process entirely. The size of the balance could be the result of insufficient synchronization of revenue and expense by periods, and overdue liabilities are always evidence of poor fiscal discipline. Therefore, the dependence between the index and the variable is negative and the value of the index is negative. In its optimal version, the indicator has a zero value, which indicates a lack of overdue liabilities.

"Share of capital expenditure in total costs (investment activity)" $(\mathrm{H})$ is an important factor for the dynamics of the investment activity of the municipality and it directly affects the process of optimizing revenues and expenditures in the coming years. The realization of investments on the basis of existing overdue liabilities is a factor for the absence of any fiscal discipline. In this sense, the high value of the index is evidence of good financial and fiscal management in the absence of overdue liabilities and a serious negative if any, this interpretation of the variable is set in the equation for the rating evaluation.

The average tax collection rate of all municipalities in the country has been taken as the basis for the construction of this rating indicator.

A verification of the value of each indicator aims to check the variation of the values in a range of minimum and maximum. i.e. the calculations are based on the continuity of the function and ensure, under equal conditions, the rating evaluation to be correct. In other words, in ensures that municipalities with inferior values of the indicator get a lower value in the rating index. The verification results are presented in the table below.

The verification confirms that the maximum variation range of each indicator in the model has a value, i.e. it is possible to calculate the rating for both indices. The values of the indices K1 and K2 have been calculated for every municipality in the country. The calculations show that the fiscal discipline of the municipalities is not predetermined by the size of the municipality and its economic, social and demographic characteristics, but rather it is the result of the actions of the operational management on the municipal level. The correlation between independant variables (financial indicators) and dependant valiable (propensity to follow the fiscal discipline) is moderate, but negative. It means that municipal governments do not have the capability to fulfill all defined indicators. The majority of small municipalities up to 10,000 inhabitants (their total number is $63 \%$ or $27 \%$ of total rutral municipalities) has not been able to carry out all the financial indicators.

The statistical test confirms that the vulnerability of municipalities to financial turmoil is not a factor for compliance or non-compliance with fiscal discipline. Therefore, non-compliance with fiscal rules and criteria should not be explained by shocks from the external environment but by the quality of financial management. 
Verification of the variables included in the composite index

Table 1

\begin{tabular}{|c|c|c|c|c|c|c|}
\hline \multirow{2}{*}{$\begin{array}{c}\text { Name of the index } \\
\text { Name of the indicator }\end{array}$} & \multicolumn{2}{|c|}{ Range of variation } & \multirow[t]{2}{*}{$\begin{array}{c}\text { There is } \\
\text { a better } \\
\text { condition for } \\
\text { values that are: }\end{array}$} & \multirow[t]{2}{*}{ Formula } & \multicolumn{2}{|c|}{$\begin{array}{l}\text { Range of variation } \\
\text { of indicator }\end{array}$} \\
\hline & $\min$ & $\max$ & & & $\min$ & $\max$ \\
\hline \multicolumn{7}{|l|}{$\begin{array}{l}\text { Characteristics } \\
\text { of the municipality }\end{array}$} \\
\hline $\begin{array}{l}\text { Share of revenue } \\
\text { of total proceeds }\end{array}$ & 0.058205556 & 0.8583013 & high & $\mathrm{LN}(1+\mathrm{A})$ & 0.0565746 & 0.61966278 \\
\hline $\begin{array}{l}\text { Covering the costs } \\
\text { of local activities } \\
\text { with revenue }\end{array}$ & 0.125351807 & 1.9037438 & high & $\mathrm{LN}(1+\mathrm{B})$ & 0.1180957 & 1.066000877 \\
\hline $\begin{array}{l}\text { Number of residents per } \\
\text { one municipal official }\end{array}$ & 26.93548387 & 583.78641 & high & $\mathrm{LN}(1+\mathrm{C})$ & 3.3298977 & 6.371246666 \\
\hline $\begin{array}{l}\text { Share of the cost for } \\
\text { salaries and benefits } \\
\text { from the total cost }\end{array}$ & 0.236695324 & 0.6911367 & high & $\mathrm{LN}(1+\mathrm{D})$ & 0.21244276 & 0.525400882 \\
\hline $\begin{array}{l}\text { Unemployment rate } \\
(\%)\end{array}$ & 2.01894317 & 65.546218 & low & $\ln (1+\mathrm{k})$ & & \\
\hline $\begin{array}{l}\text { Average annual income } \\
\text { per person (BGN) }\end{array}$ & 4859 & 25043 & high & $\mathrm{LN}(1+(\mathrm{n} / \mathrm{MAX}(\mathrm{nn})$ & 0.17733102 & 0.693147181 \\
\hline $\begin{array}{l}\text { Production } \\
\text { of enterprises } \\
\text { (BGN thousand) }\end{array}$ & 383 & 55541798 & high & $\mathrm{LN}(1+(\mathrm{m} / \mathrm{MAX}(\mathrm{mm})$ & 0 & 0.693147181 \\
\hline \multicolumn{7}{|l|}{$\begin{array}{l}\text { Propensity to violation } \\
\text { of fiscal discipline }\end{array}$} \\
\hline $\begin{array}{l}\text { Budget balance } \\
\text { compared to total } \\
\text { revenues }\end{array}$ & -0.83996297 & 0.3678842 & high & $\mathrm{LN}(1+\mathrm{G})$ & -1.83235 & 0.313265155 \\
\hline $\begin{array}{l}\text { Debt as a\%age of } \\
\text { projected revenue and } \\
\text { equalization subsidy }\end{array}$ & 0 & 2.7034626 & low & $\mathrm{LN}(1+\mathrm{E})$ & 0 & 1.30926822 \\
\hline $\begin{array}{l}\text { Overdue liabilities } \\
\text { as a } \% \text { age of planned } \\
\text { revenue and } \\
\text { equalization subsidy }\end{array}$ & 0 & 2.7850187 & low & $\mathrm{LN}(1+\mathrm{F})$ & 0 & 1.331050832 \\
\hline $\begin{array}{l}\text { Share of capital } \\
\text { expenditure from }\end{array}$ & 0.015718574 & 0.5318932 & conditional & $\mathrm{LN}(1+\mathrm{H})$ & 0.01559632 & 0.426504348 \\
\hline $\begin{array}{l}\text { the total expenditure } \\
\text { (investment activity); }\end{array}$ & & & conditional & $\mathrm{LN}(1-\mathrm{H})$ & -0.0158434 & -0.759058777 \\
\hline $\begin{array}{l}\text { Collection rate of real } \\
\text { estate tax }(\%)\end{array}$ & 0.4168 & 1 & high & LN(I/average(II) & -0.5304024 & 0.344746373 \\
\hline $\begin{array}{l}\text { Collection rate of } \\
\text { vehicle tax }(\%)\end{array}$ & 0.3179 & 1 & high & LN(J/average $(\mathrm{JJ})$ & -0.7289108 & 0.41710762 \\
\hline $\begin{array}{l}\text { Average collection rate } \\
\text { of both taxes }\end{array}$ & 0.3958 & 0.9436 & high & & & \\
\hline
\end{tabular}

Source: data from the Ministry of Finance and own calculations. 
Index $\mathrm{K} 2$ indicates that the propensity for violating fiscal discipline and its value is used as basis for ranking municipalities. In relation to the rating evaluation scale, rating values below 0 (zero) denote risk or violation of the fiscal stability of the municipality as a result of poor management, and vice versa. If $\mathrm{K} 2$ has positive values, it can be assumed that municipalities comply with the financial indicators and they are able to follow a fiscal discipline. The assessment shows that many municipalities have similar values of the index K2 below 0 , which indicates that the risk of non-fulfillment of the financial indicators could happen in the future and there is a real risk of violation of the fiscal discipline.

The analysis shows that compliance with fiscal discipline is a feature of the management of the municipality and not of the surrounding economic and business environment.

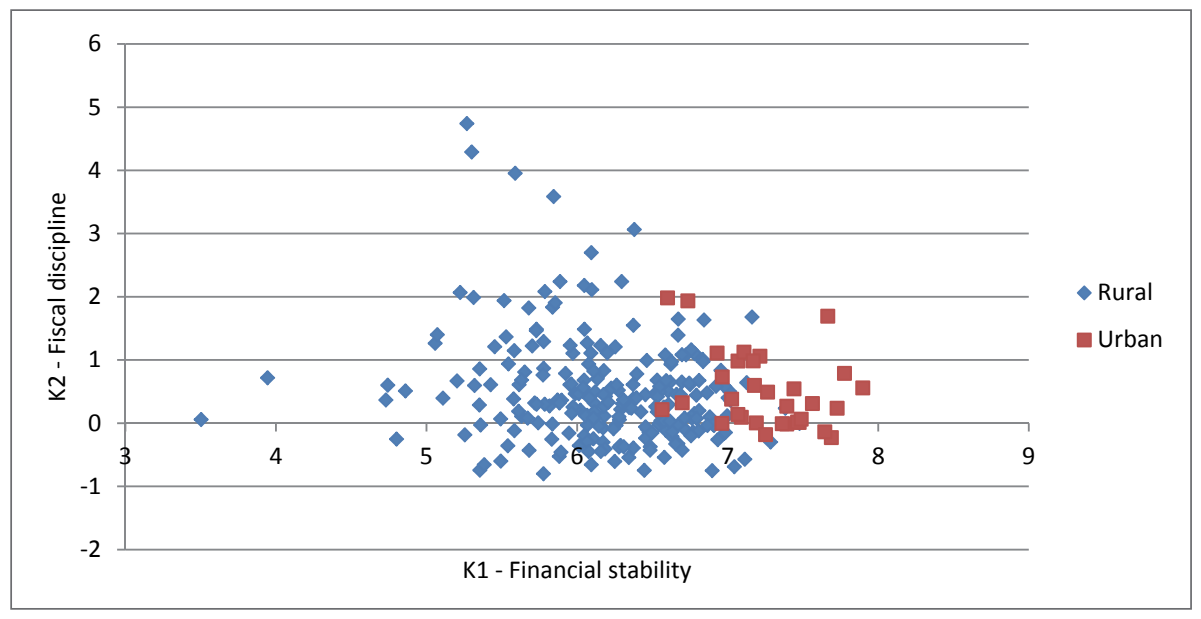

Fig. 2. Distribution of municipalities according to propensity for violating fiscal discipline and financial stability.

Source: data from the Ministry of Finance and author's own calculations.

The Figure above demonstrates the results of the indicators (K1 and K2) and includes all municipalities in Bulgaria.

The value of index $\mathrm{K} 1$ assessing economic, social and administrative potential of rural municipalities is lower by $17 \%$ in comparison with bigger urban municipalities. The average aggregated value of index K1 is 6.195999 for all rural municipalities, and the average value of index K1 for urban municipalities is 7.252331148.

Regarding index K2, which evaluates the propensity to violate financial discipline of rural municipalities, the average aggregated value is 0.4859 , and - for urban municipalities - it is 0.501465657 . The deviation of the value across the rural municipalties is around $3.19 \%$, which shows that the financial indicators have no significant impact on the financial discipline, and that compliance with financial indicators is a matter of financial management. (The allocation of the rural municipalities illustated by the figure above confirms this statement). The correlation 
analysis shows that financially sound municipalities are more likely to break financial discipline because the correlation is negative ${ }^{8}$.

The general conclusion is that there are no drastic differences in the following financial discipline of rural and urban municipalities, even though rural municipalities are characterized by a higher dispersion. This can be explained by a stronger exposure to external shocks as their economies are weaker and there are no financial buffers to absorb the negative effects of financial shocks.

\section{Concluding remarks: toward fiscal discipline and financial stability}

Rural mucipalities differ significantly in their size, population densities and economic capacity. The defined financial indicators could be considered as a staring point and a benchmark against which the financial performance will be compared. By studying the financial state of Bulgarian rural municipalites, the author found that the fiscal stability should be understood not only in terms of carring out the financial indicators, but also in terms of financial management and level of external controls.

The model for assessment of fiscal stability of rural municipalities developed in this study indicates the following findings:

- The financial situation of the local governments located in rural territories is sensitivite to the population rate, residents' income and the unemployment rate. The assessment shows that it is necessary to take into account the impacts of various external factors and the efficiency of the administration in order to improve the financial management of the local authorities.

- External factors and macro-environment do not predetermine the level of fiscal discipline, which means that fiscal discipline is a function of the quality of financial and operative management of the municipality's finances.

- There is a statistically significant dependency between the different components of the fiscal discipline and specific indicators of the municipalities - demographic, social, economic and administrative. In other words, it is possible to construct a profile of municipalities where the risk of negative impact of the external environment is higher than in the other municipalities.

- The correlation analysis shows that there is no significant dependency between the fiscal discipline and the size of the municipality, i.e. the compliance with fiscal discipline does not differ between urban and rural municipalities. The willingness to observe fiscal discipline is a problem of financial management and does not depend on the type and size of the municipality.

- Last but not least, the analysis shows that the current methodology set by the Ministry of Finance for assessment of the execution of municipal's budget does not take into account the level of fulfilment and the value of financial indicators, it considers only compliance or not compliance without taking into account the value of indicators, and this is an important omission.

\footnotetext{
${ }^{8}$ This dependence could also be determined by the influence of other factors which are beyond the scope of this article. Such factors include, for instance, political factors, disasters, accidents, local macroeconomic shocks, etc.
} 


\section{References}

EC (2011). Council Directive 2011/85/EU of $8^{\text {th }}$ November 2011 on Requirements for Budgetary Frameworks of the Member States; EC: 2011; EU Stability and Growth Pact Retrieved from: https://eur-lex.europa.eu/LexUriServ/LexUriServ.do?uri=OJ:L:2011:306:0041:0047 :EN:PDF.

Harizanova, H., Stoyanova, Z. (2012). Development of the Rural Regions in Bulgaria under the Period of Relocating of CAP. Scientific Papers Series Management, Economic Engineering in Agriculture and Rural Development, Vol. 12, Issue 3, pp. 65-68 .

Hendrick, R. (2004). Assessing and measuring the fiscal health of local government: Focus on Chicago suburban municipalities. Urban Affairs Review, vol. 40, No. 1, pp. 78-114.

Hendrick, R. (2011). Managing the Fiscal Metropolis: The Financial Policies, Practices, and Health of Suburban Municipalities. Washington, DC: Georgetown University Press, Chapter 2, pp. 20-29.

Kloha, P., Weissert, C., Kleine, R. (2005). Developing and Testing a Composite Model to Predict Local Fiscal Distress. Public Administration Review, 65,3, pp. 313-323.

Local Taxes and Fees Act (2019). Retrieved from: http://www.bulgaria-tax-law.bg/local-taxes-fees.html.

Ministry of Finance Bulgaria Statistics (2018). (data for financial indicators of municipalities). Retrieved from: https://www.minfin.bg/bg/810.

Municipal Budget Act (2013). Retrieved from: https://lex.bg/laws/ldoc/2134393857.

National Statistical Institute (2018). Population and Demographic Processes in 2018. Retrieved from: http://www.nsi.bg/en/content/17130/прессъобщение/population-and-demographic-processes-2018.

OECD (2013). Government at a Glance 2013, Chapter 2 Stategic Governace, p.50 Retrieved from: https://www.oecd-ilibrary.org/docserver/gov_glance-2013-en.pdf?expires=15669946 44\&id=id\&accname $=$ guest $\&$ checksum $=048018$ A3FA150F8220742ED9895431C7.

Petrov, S. (2017). Financial Sustainability in Rural Areas in Bulgaria. Agricultural Economics and Management, 62,2, pp. 49-54, pp. 54.

Public Finance Act (2017). Retrieved from: https://www.lex.bg/laws/ldoc/2135837967.

State Budget Act (2018). Retrieved from: http://dv.parliament.bg/DVWeb/showMaterialDV.jsp? idMat $=120521$.

Wang X., Dennis L., Sen Y. (2007). Measuring Financial Condition: A Study of U.S. States. Public Budgeting \& Finance / Summer 2007, pp. 1-22. DOI: 10.1111/j.1540-5850.2007.00872.x 


\title{
OCENA CZYNNIKÓW STABILNOŚCI FISKALNEJ GMIN WIEJSKICH: PRZYPADEK BUŁGARII
}

\begin{abstract}
Abstrakt
Kwestia stabilności finansowej i zrównoważenia wplywa na autonomię samorzadów lokalnych i realizowanie powierzonych im obowiązków. Niniejszy artykut bada stabilność finansowa bułgarskich gmin wiejskich oraz wptyw czynników społecznych, gospodarczych i demograficznych na ich wyniki finansowe. Badaniem objęto wszystkie 231 gminy wiejskie w Butgarii. Niniejszy artykut ma na celu zbadanie zdolności samorzadów lokalnych do spetniania wskaźników finansowych zdefiniowanych przez bułgarska ustawe o finansach publicznych (2017). Autor proponuje model oceny stabilności finansowej gmin wiejskich, który może być wykorzystywany przez władze lokalne na wszystkich szczeblach, do monitorowania zarzadzania finansami gmin wiejskich oraz oceny ich skłonności do przestrzegania zdefiniowanych wskaźników fiskalnych.
\end{abstract}

Słowa kluczowe: gminy wiejskie, stabilność finansowa, stabilność fiskalna, model oceny, wskaźniki finansowe, dyscyplina finansowa.

Accepted for print: 13.09.2019.

Unless stated otherwise all the materials on the website are available under 